\title{
Chemical Signatures of New Pesticides in the Bovine and Caprine Milk Samples Collected from Western Uttar Pradesh (India)
}

\author{
Suresh V. S. Rana*, Yeshvandra Verma, Uday Veer Rathi and Lalit Mohan Vashistha \\ Department of Toxicology, Chaudhary Charan Singh University, Meerut-250004,Uttar Pradesh, India; sureshvs_rana@ \\ yahoo.com, yeshvandra@gmail.com
}

\begin{abstract}
Raw buffalo, cow and goat milk collected from different locations of Northern India has been analyzed for suspected pesticides viz. azimsulfuron, cypermethrin, thiabendazole, crotonolactone, fluoxastrobin, aldicarb and carbofuran. Buffalo milk tested positive for azimsulfuron $(4.51 \mathrm{ng} / \mathrm{ml})$, cypermethrin $(7.21 \mathrm{ng} / \mathrm{ml})$ and thiabendazole $(4.57 \mathrm{ng} / \mathrm{ml})$. Cow's milk did not show the presence of cypermethrin and thiabendazole, however, azimsulfuron $(0.86 \mathrm{ng} / \mathrm{ml})$, crotonolactone $(4.73$ $\mathrm{ng} / \mathrm{ml})$ and fluoxastrobin $(0.54 \mathrm{ng} / \mathrm{ml})$ were determined. Milk of the goats registered the presence of carbafuron $(7.69 \mathrm{ng} /$ $\mathrm{ml}$ ), fluoxastrobin $(5.41 \mathrm{ng} / \mathrm{ml})$ and azimsulfuron $(5.28 \mathrm{ng} / \mathrm{ml})$. Since all the milching cattle are herbivorous, these pesticides entered animal through food chain. The consumption of milk containing these pesticides even in traces may be hazardous to human population of Northern India. Concurrent presence of these pesticides may be more hazardous due to their synergistic manifestations. New synthetic molecules like azimsulfuron, fluoxastrobin and crotonolactone may pose severe public health problems.
\end{abstract}

Keywords: Carbamates, Milk, Organochlorines, Organophosphates, Pyrethroids and Public Health

\section{Introduction}

Milk is nearly perfect natural food used worldwide in all segments of population and in all stages of human life ${ }^{1}$. According to some estimates, about 730 million tons of milk was produced in $2011^{2}$. India is world's largest producer of milk and is the leading exporter of skimmed milk powder. However, eighty percent of its milk supply comes from the unorganized sector of small dairy farmers. Quality of milk and milk products has been a matter of concern especially from public health point of view. Regulatory agencies viz. Environment Protection Agency (EPA) and Food and Drug Administration (FDA) monitor the quality of milk through FIFRA (1948 amended in 1972, 1975, 1978, and 1996) and Food, Drug and Cosmetics Act (1906, amended in 1958, 1960, 1962, 1968, 1976 and 1997). Food Safety and Standards Act (2006), ensures the availability of safe and wholesome food for human consumption in India.
Nevertheless, several episodes/incidents of milk poisoning have occurred in recent past in different countries. These include Morinaga milk poisoning outbreak in Japan ${ }^{3}$, milk contamination by dioxins in Belgium ${ }^{4}$, baby milk scandal in China ${ }^{5}$ and milk tea poisoning in Manila. Periodic quality analyses of milk samples in different countries have confirmed the presence of several pesticide residues in dairy milk viz. Pakistan ${ }^{6}, \operatorname{Iran}^{7}$, Egypt $^{8}$ and Poland 9 Several reports from different regions of India have also documented the presence of environmentally significant organo chlorine and organophosphate pesticides in the dairy milk with special reference to Bihar ${ }^{10}$, Jharkhand ${ }^{11}$, Bundelkhand ${ }^{12}$, Haryana ${ }^{13}$ and Rajasthan ${ }^{14}$.

Since a ban on the production, commercial and agricultural use of many pesticides including a few Persistent Organic Pollutants (POPs) has been imposed by several countries including India, farmers are reportedly using alternate pesticides. Although toxic properties of many of

*Author for correspondence 
these are known in literature, biological monitoring through milk and other dairy products remains to be performed.

Therefore, the main objective of the present study was to analyse raw milk of buffalo, cow and goat of Western Uttar Pradesh (India) for new molecules viz; fluoxastrobin, an organochlorine., azimsulfuron and thiabendazole, the organophosphates., aldicarb and carbofuran, the carbamates and cypermethin, a pyrethroid. The study, first of its kind, from agriculturally rich area of western Uttar Pradesh (India) is expected to be important from food safety and public health point of view.

\section{Materials and Methods}

Petroleum ether, hexane and acetone of HPLC grade were purchased from Merck (India). Reagent grade anhydrous sodium sulphate and sodium oxalate and other reagents were purchased from Hi-Media Laboratories, Mumbai. Absolute ethyl alcohol of A.R. grade was purchased from Bengal Chemicals (India). Raw milk samples were collected randomly from different villages of the districts of Uttar Pradesh state of India viz. Muzaffarnagar, Hapur, Bijnor and Meerut (figure 1). The samples were collected during July-October, 2017 with a frequency of 10 samples/locality/ per cattle/month. They were transported in liquid nitrogen and stored in $25 \mathrm{ml}$ clean sterilized bottles at $-80^{\circ} \mathrm{C}$ in the laboratory for further analyses. Pasteurized milk samples were also procured at random from the local market and stored at $-80^{\circ} \mathrm{C}$ till their analysis. All the milk samples collected from different villages/localities were analyzed for their physico-chemical properties viz. $\mathrm{pH}$ by a $\mathrm{pH}$ meter (Systronics, India), specific gravity by a lactometer and fat(\%) by a Gerber's butyrometer. Those samples having a

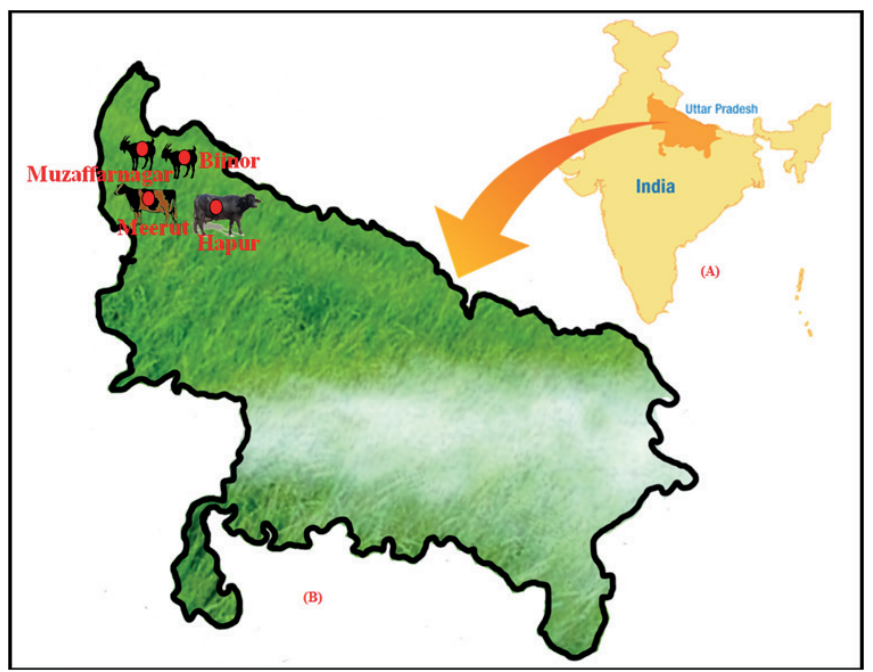

Figure 1. (A) shows the location of Uttar Pradesh state of India (B) shows the location of four districts (sampling sites) within Uttar Pradesh state of India. specific gravity of less than 1.010 and more than 1.040 were discarded. Similarly, the milk samples having $\mathrm{pH}$ less than 6.0 and more than 7.0 were not used in this study. The lipid content of the representative milk samples collected from buffaloes ranged from 6.0 to $7.5 \mathrm{~g} / 100 \mathrm{ml}$. In cow milk, it ranged from 3.0 to $4.5 \mathrm{~g} / 100 \mathrm{ml}$, whereas in goat milk the range was between 3.5 to $4.5 \mathrm{~g} / 100 \mathrm{ml}$. Extraction of pesticide residues from milk samples was performed following the standard procedures of $\mathrm{FAO} / \mathrm{WHO}^{15}$. Homogenized milk $(15 \mathrm{ml})$ was mixed with $15 \mathrm{ml}$ absolute ethyl alcohol and $15 \mathrm{ml}$ of petroleum ether using a $50 \mathrm{ml}$ screw cap centrifuge tube. The contents of the tube were vigorously mixed using a vortex mixer for $1 \mathrm{~min}$. Sodium oxalate $(0.5 \mathrm{~g})$ was added to the tube and immediately vortexed for $1 \mathrm{~min}$. The sample was then centrifuged for $25 \mathrm{~min}$ at $5000 \mathrm{rpm}$. A $5 \mathrm{ml}$ aliquot was collected and filtered. The filtrate was transferred to a separating funnel and equal amount of petroleum ether was added. The funnel was repeatedly and vigorously shaken for 20-30 min. The aqueous and solvent phases were collected separately. The organic layer was allowed to pass through the cone of Whatman filter paper containing anhydrous sodium sulphate. The aqueous layer was extracted again for 2-3 times with petroleum either. The organic layer was evaporated to dryness. The residue was dissolved in $2 \mathrm{ml}$ hexane-acetone mixture $(8: 2)$ and then centrifuged for $1 \mathrm{~min}$ at $1500 \mathrm{rpm}$ at $4^{\circ} \mathrm{C}$. The aliquot of the final upper layer was transferred to auto sampler vial for GC-MS analysis. Summarized extraction procedure is shown in (figure 2). Different characteristics of examined pesticides such as molecular formulae, molecular mass, retention time, area (\%) and recovery (\%) are summarized in (table 1). An Agilent GC-MS model $5975 \mathrm{c}$ equipped with $15 \mathrm{~m} \times 0.25 \mathrm{~mm}$ capillary column and a Flame Ion Detector (FID) was used for pesticide analysis. The final GC-FID settings for present analysis were as follows.

The injection volume was $1 \mu \mathrm{L}$ and the helium carrier gas flow rate was maintained at $1.0 \mathrm{ml} / \mathrm{min}$. The injector and detector temperatures were maintained at $280^{\circ} \mathrm{C}$. The initial temperature of $100^{\circ} \mathrm{C}$ was held for $2 \mathrm{~min}$. and then increased to $180^{\circ} \mathrm{C}$ at $30^{\circ} \mathrm{C} / \mathrm{min}$ and held there for $32 \mathrm{~min}$ and further increased to $280^{\circ} \mathrm{C}$ at $16^{\circ} \mathrm{C} / \mathrm{min}$ and held for $20.75 \mathrm{~min}$. The recovery (\%) of pesticides was conducted according to the method suggested by Lehotay ${ }^{16}$ applying the following formula:

Percent recovery $=\frac{\text { standard peak area in sample }}{\text { standard peak area }} \times \frac{\text { internal standard peak area }}{\text { internal standard peak area in sample }} \times 100$ 


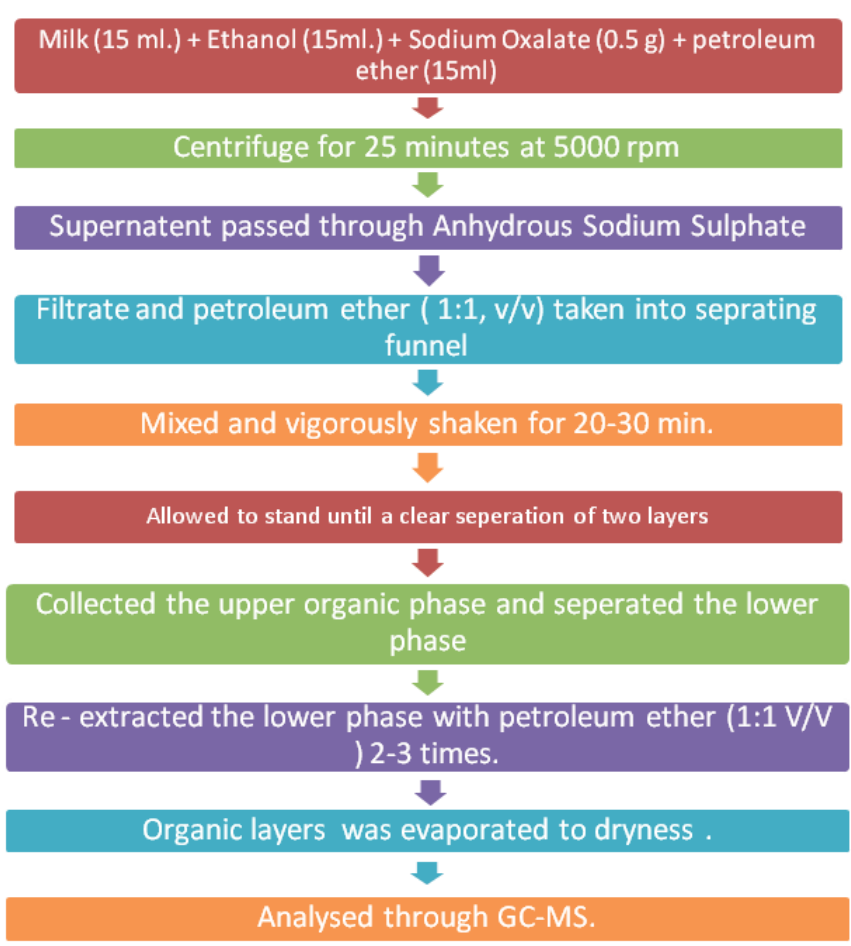

Figure 2. Flow diagram of extraction procedure.

\section{Results}

Milk samples analyzed for azimsulfuron, an organo phosphate showed highest concentration in goat milk. Least concentration was recorded in cow's milk, whereas, lower concentration was recorded in buffalo's milk (Table 1). Another organophosphate, thiabendazole was present only in buffalo milk and was wanting in cow and goat milk (Table 1). The results suggest that azimsulfuron constitutes a potential human health risk. Milk analysis for an organochlorine compound, fluoxastrobin, also showed highest concentration in goat milk, followed by cow's milk. This compound was absent in buffalo's milk. (Table 1). Carbamates i.e. aldicarb and carbofuran were also analysed in milk samples. While carbofuran was present in goat milk, it was absent in buffalo's and cow's milk (Table 1). Aldicarb was present only in cow's milk and absent in goat and buffalo milk (Table 1). Amongst pyrethroids, cypermethrin was present in buffalo's milk and was wanting in cow milk and goat milk. (Table 1). Ketone group pesticide, crotonolactone was present only in cow's milk and was wanting in buffalo and goat milk (Table 1).

Table 1. Pesticides detected in milk samples

\begin{tabular}{|c|c|c|c|c|c|c|c|}
\hline Pesticides & Classification & $\begin{array}{l}\text { Molecular } \\
\text { Formulae }\end{array}$ & $\begin{array}{c}\text { Molecular } \\
\text { Mass (g/mol) }\end{array}$ & $\begin{array}{c}\text { Retention } \\
\text { Time } \\
\text { (min.) }\end{array}$ & Area (\%) & Recovery (\%) & $\begin{array}{l}\text { Concentration } \\
(\mathrm{ng} / \mathrm{ml})\end{array}$ \\
\hline \multicolumn{8}{|l|}{ (A) Buffalo } \\
\hline Azimsulfuron & $\begin{array}{l}\text { Organophosphate } \\
\text { (Thiol) }\end{array}$ & $\mathrm{C}_{13} \mathrm{H}_{16} \mathrm{~N}_{10} \mathrm{O}_{5} \mathrm{~S}$ & 424.39 & 7.870 & 17.09 & 64 & $4.51 \pm 0.78$ \\
\hline Cypermethrin & Pyrethroid & $\mathrm{C}_{22} \mathrm{H}_{19} \mathrm{Cl}_{2} \mathrm{NO}_{3}$ & 416.30 & 7.870 & 17.09 & 53 & $7.21 \pm 0.10$ \\
\hline Thiabendazole & $\begin{array}{l}\text { Organophosphate } \\
\text { (Thiol) }\end{array}$ & $\mathrm{C}_{10} \mathrm{H}_{7} \mathrm{~N}_{3} \mathrm{~S}$ & 201.24 & 19.223 & 5.68 & 56 & $4.57 \pm 0.27$ \\
\hline \multicolumn{8}{|l|}{ (B) Cow } \\
\hline Crotonolactone & Ketone & $\mathrm{C}_{4} \mathrm{H}_{4} \mathrm{O}_{2}$ & 84.07 & 14.428 & 16.44 & 51 & $4.73 \pm 0.70$ \\
\hline Fluoxastrobin & Organochlorine & $\mathrm{C}_{21} \mathrm{H}_{16} \mathrm{ClFN}_{4} \mathrm{O}_{5}$ & 458.83 & 15.235 & 3.25 & 90 & $0.54 \pm 0.12$ \\
\hline Azimsulfuron & $\begin{array}{l}\text { Organophosphate } \\
\text { (Thiol) }\end{array}$ & $\mathrm{C}_{13} \mathrm{H}_{16} \mathrm{~N}_{10} \mathrm{O}_{5} \mathrm{~S}$ & 424.39 & 7.887 & 1.00 & 50 & $0.86 \pm 0.44$ \\
\hline Aldicarb & Carbamate & $\mathrm{C}_{7} \mathrm{H}_{14} \mathrm{~N}_{2} \mathrm{O}_{2} \mathrm{~S}$ & 190.26 & 15.131 & 0.57 & 68 & $0.22 \pm 0.05$ \\
\hline \multicolumn{8}{|l|}{ (C) Goat } \\
\hline Carbofuran & Carbamate & $\mathrm{C}_{12} \mathrm{H}_{15} \mathrm{NO}_{3}$ & 221.26 & 16.551 & 22.61 & 47 & $7.69 \pm 0.92$ \\
\hline Fluoxastrobin & Organochlorine & $\mathrm{C}_{21} \mathrm{H}_{16} \mathrm{ClFN}_{4} \mathrm{O}_{5}$ & 458.83 & 15.103 & 30.25 & 59 & $5.41 \pm 0.74$ \\
\hline Azimsulfuron & $\begin{array}{l}\text { Organophosphate } \\
\text { (Thiol) }\end{array}$ & $\mathrm{C}_{13} \mathrm{H}_{16} \mathrm{~N}_{10} \mathrm{O}_{5} \mathrm{~S}$ & 424.39 & 7.882 & 21.87 & 59 & $5.28 \pm 1.19$ \\
\hline
\end{tabular}

Results are expressed as mean \pm SE $(n=5)$. 


\section{Discussion}

Several studies have used milk as a bioindicator of bioconcentration of environmentally persistent organic micropollutants such as pesticides ${ }^{17}$. Pesticide residues in milk originate from contaminated feed, grass or corn silage and/or direct application of pesticides on dairy cattle. Though the sale and use of hazardous chemicals listed under Annex 'A' of the Stockholm convention are regulated in India by the Pesticide Act (1968) and Insecticide Rules (1971), they have been substituted by other organochlorines, organophosphates, carbamates as well as pyrethroids. The purpose of present study was to verify the presence of these alternate toxic molecules in raw dairy milk consumed by human population of Northern India. It is evident from present results that raw daily milk collected from all the three sources and from different locations is contaminated with azimsulfuron. Highest concentration was recorded in goat milk. This observation may be linked with the food and feeding behavior of the goats that mainly eat the leaves. Azimsulfuron is an herbicide that belongs to the chemical group of sulfonylureas. They constitute new class of compounds widely used to control weeds in several crops viz. rice, wheat, maize, barley, sugar beet and tomato. Azimsulfuron affects sensitive weeds through inhibition of the enzyme Acetolactate Synthetase (ALS). Inhibition of ALS stops cell division and subsequent growth in plants. Azimsulfuron is mainly adsorbed by the leaves and shoots. Since goats relish leaves, it is translocated to them through food and finally becomes residual in milk. Weeds consumed though hay of wheat, rice and maize by cows and buffalos allow azimsulfuron to enter their food chain. It causes low acute toxicity in mammals. Mutagenic, carcinogenic and reproductive effects have not so far been established. Despite numerous beneficial properties, goat milk has lipophilic properties, therefore, tends to accumulate various pesticides that are poisonous ${ }^{18-20}$. It was interesting to note that, thiabendazole, an organophosphate was present only in buffalo's milk. It is used as a parasiticide to control roundworms, hookworms and other helminth parasites of livestock. It is expected to enter the buffaloes through fodder that have been treated with this fungicide. Maximum Residual Limit (MRL) as available in literature is $50 \mathrm{ppb}^{21}$. The main sources of organophosphate contaminants in milk animals are forage and fodder followed by drinking water and soil ingested during grazing ${ }^{22-24}$. In animal bodies, these compounds are easily distributed from the alimentary tract and accumulate mainly in liver, adiposetissue and milk $^{25,26}$. Organophosphate pesticides are easily hydrolyzed and therefore, do not persist in the environment. However, plausibility of their accumulation in milk and eggs poses risks for human health ${ }^{27}$. Another fungicide, fluoxastrobin, was detected in goat and cow's milk but was wanting in buffalo milk. Fluoxastrobin is considered as a novel strobilurin analog. The biochemical mechanism of action of strobilurins consists of interaction with the ubiquinone binding site of the mitochondrial $\mathrm{BCl}$ complex (complex III) in fungal cells thereby preventing the oxidation of bihydroquinone and the transfer of electrons to cytochrome $\mathrm{C}^{28}$. Its $\mathrm{MRL}$ is $0.5 \mathrm{mg} /$ $\mathrm{kg}$. In some reports it is $0.02 \mathrm{ppb}$. Use of milk contaminated with fluoxastrobin may cause respiratory problems ${ }^{29}$. Thus consumption of goat milk may be more hazardous than cow's milk. Contrarily, goat milk is usually considered more beneficial than cow's milk ${ }^{30,31}$. Cow's milk and goat milk both have similar protein content but goat milk proteins are assimilated more easily ${ }^{32}$. Goat milk has lipophilic properties similar to cow's milk, but seems to accumulate higher concentration of strobilurins. Another pesticide that registered its presence in goat milk was carbofuran. It was absent in buffalo's and cow's milk. It is one of the most toxic carbamate pesticides and used to control insect infestation in a variety of crops. It is a systemic insecticide. Though it is absorbed by the roots but insecticidal concentrations are attained by leaves. Browsing of the leaves allows it to enter into the goats. MRL for carbofuran is $0.05 \mathrm{mg} / \mathrm{kg}$. It is classified as an extremely hazardous substance in the United States as defined in the section 302 of the U.S Emergency Planning and Community Right to Know Act (42 U.S.C. 11002). Import, manufacture and use of carbofuran has also been banned in India. Feed stuff has been suggested as main source of milk contamination in a study made in Brazil ${ }^{27}$. Consumption of milk contaminated with carbofuran may cause inhalation and neurotoxicity. It has been reported not to cause teratogenic, mutagenic or carcinogenic toxicity. Present results show that another carbamate pesticide, aldicarb was present only in the raw milk collected from cows. Aldicarb is one of the most widely used pesticides which is primarily used as nematicide. MRL for aldicarbis $0.002 \mathrm{mg} / \mathrm{kg}^{21}$. Reports on the presence of aldicarb in raw dairy milk are scarce. However, Kan et al..$^{33}$ suggested that aldicarb enters the milk through feed crops. Primary route of human exposure to aldicarb is the consumption of contaminated food and water. Contaminated milk may also induce its toxicity. Cholinesterase inhibition is the primary cause of aldicarb's toxicity. Range of symptoms include muscarinic (nausea, vomiting, diarehea, miosis) and nicotinic (muscular effects, high blood pressure and hyperglycemia) ${ }^{34}$. Manufacture, import and use of aldicarb has been banned in India,however, its presence in cow's milk confirms its persistence in the environment. Results on cypermethrin, a synthetic pyrethroid showed that it was present only in buffalo milk. Its use in any form is restricted in India. MRL of cypermethrin in milk is $0.010 \mathrm{mg} / \mathrm{kg}$. It is a fast acting neurotoxin.It has been classified as a possible 
human carcinogen. Through large scale agricultural applications, it enters the food chain of buffaloes. Although, fodder of buffaloes and cows is similar, it was wanting in cow's milk. Depurination of cypermethrin may be quicker in cows than buffaloes. Absence of these molecules in the pasteurized milk samples that were analyzed as positive control is welcome observation from biosafety point of view. Overall results suggest that though the concentration of selected pesticides in raw milk samples is much lower, at present, in comparison to MRL recommended by United States Food and Drug Administration, persistent consumption of raw milk by human population, especially infants might lead to serious and long lasting public health problems.

\section{Acknowledgement}

Authors are highly thankful to Director, Forensic Science Laboratory, Delhi for allowing the use of its GC-MS facility. The technical support extended by our colleagues i.e. Kavita Rana, Varsha, Huma and Meenu is also acknowledged. Authors would like to express sincere thanks to all farmers and owners of cattles for allowing the use of milk samples for this study.

\section{Conflict of Interest}

The authors declare no conflict of interest in present study.

\section{References}

1. Davies JF, Freed VH, Whittemore FW. An Agro Medical Approach to Pesticide management, University of Miami School of Medicine, Coral Gables; 1986.

2. FAO[Internet].2012.Availablefrom:http://www.fao.org/ fileadmin/templates/est/COMM_MARKETS_MONIT ORING/Dairy/Documents/FO_May_2015- Dairy.pdf

3. Dakeishi M, Murata K, Grandjean P. Long-term consequences of arsenic poisoning during infancy due to contaminated milk powder. Environmental Health. 2006; 5:31. https://doi.org/10.1186/1476-069X-5-31. PMid:17076881. PMCid:PMC1635412

4. Bernard A, Gilbert $\mathrm{H}$. The Belgian PCB/Dioxin incident: Analysis of the food chain contamination and health risk evaluation. Environmental Research. 2002; 88:1-18. https://doi.org/10.1006/enrs.2001.4274. PMid:11896663

5. Ruijia Y, Huang W, Zhang L. Milk adulteration with melamine in China: Crisis and response. Quality Assurance and Safety of Crops \& Foods. 2009; 1:11116. https://doi.org/10.1111/j.1757-837X.2009.00018.x
6. Shahzadi N, Imran M, Sarwar M, Hashmi AB, Wasim M. Identification of pesticides residue in different samples of milk. Journal of Agroalimentary Processes and Technologies. 2013; 19:167-72.

7. Ashnagar A, Gharib NN, Cheraghi FM. Determi nation of Organochlorine pesticide residues in cow's milk marketed in Ahwaz city of Iran. International Journal of PharmTech Research. 2009; 1:247-51.

8. Shaker EM, Elsharkawy EE. Organochlorine and organophosphorus pesticide residues in raw buffalo milk from agroindustrial areas in Assiut,Egypt. Environmental Toxicology and Pharmacology. 2015; 39:433-40. https://doi. org/10.1016/j.etap.20 14.12.005. PMid:25575291

9. Witczak A, Pohorylo A, Malek AM. Assessment of health risk from organochlorines xenobiotics in goat milk for consumers in Poland. Chemosphere. 2016; 148:395-402.https://doi.org/10.1016/j.chemo sphere.2016.01.025. PMid:26829307

10. Nath A, Vendan SE, Priyanka, Singh JK, Singh CK, Kumar S. Carcinogenic pesticides residue detection in cow's milk and water samples from Patna, India. Current Trends in Biotechnology and Chemical Research. 2013; 3:1-8.

11. Barman RM, Mishra BK, Barman A. OCP residues analysis in cow milk of Dhanbad city, Jharkhand, India. International Journal of Applied and Pure Science and Agriculture. 2016; 2:1-11.

12. Nag SK, Raikwar MK. Organochlorine pesticide residues in Bovine milk. Bulletin of Environmental Contamination and Toxicology. 2008; 80:5-9. https://doi.org/10.1007/s00128-007-9276-6. PMid:17940716

13. Kaushik CP, Sharma HR, Gulati D, Kaushik A. Changing patterns of organochlorines pesticide residues in raw bovine milk from Haryana, India. Environmental Monitoring and Assessment. 1999; 182:467-75. https://doi.org/10.1007/s10661-0111890-4. PMid:21331758

14. John PJ, Bakore N, Bhatnager P. Assessment of Organochlorine Pesticide Residue Levels in Dairy Milk and Buffalo Milk from Jaipur City, Rajasthan, India. Environment International. 2001; 26:231-6. https://doi.org/10.1016/S0160-4120(00)00111-2

15. FAO/WHO. Joint FAO/WHO Food Standards Programme-Codex Alimentarius CommissionCodex Alimentarius- Volume II. Pesticide Residues 
in Food. Food Agriculture Organization/World Health Organization, Rome; 1993.

16. Lehotay SJ. Quick, easy, cheap, effective, rugged and safe approach for determining pesticide residues. Methods in Biotechnology. Vol.19- Pesticide Protocols. Totowa, NJ: Humana Press Inc.; 2006. https://doi.org/10.1385/1 59259-929-X:239

17. Kampire E, Kiremire BT, Nyanzi SA, Kishimba M. Organochlorine pesticide in fresh and pasteurized cow's milkfrom Kampala markets. Chemosphere. 2011;84:9237. https://doi.org/10.1016/j.chemosphere.2011.06.011. PMid:21737114

18. Duarte-Davidson R, Jones KC. Screening the environmental fate of organic contaminants in sewage sludges applied to agricultural soils: The potential for trans fer to plants and grazing animals. Science of the Total Environment.1996; 185:59-70.https://doi. org/10.1016/0048-9697(96)05042-5

19. Fries GF. Ingestion of sludge applied organic chemicals by animals. Science of the Total Environment. 1996; 185:93108. https://doi.org/10.1016/0048-9697(96)05045-0

20. Gupta PK. Pesticide exposure- Indian scene. Toxico logy. 2004; 198:83-90. https://doi.org/10.1016/j.tox.200 4.01.021. PMid:15138033

21. USFDA (U.S. Food and Drug Administration) [Inter net].2014. Pesticides residue monitoring program fiscal year 2014 pesticide report. Available from: http:// www.fda.gov/food/foodborneillnesscontaminants/ pesticides/default.htm

22. Bluthgen A. Contamination of milk from feed. Bulletin of the International Dairy Federation. 2000; 356:43-7.

23. Heck MC, Santos J, Bogusz S, Costabeber I, Emanuelli T. Estimation of children exposure to organochlorine compounds through milk in Rio Grande do Sul, Brazil. Food Chemistry. 2007; 102:288-94. https://doi. org/10.1016/j.foodchem.2006.05.019

24. Rychen G, Jurjanz S, Fournier A, Toussaint H, Feidt C. Exposure of ruminants to persistent organic pollutants and potential of decontamination. Environ. Sci. pollut. Res. 2014; 21:6440-7. https://doi.org/10.1007/s11356013-1882-8. PMid:23764985

25. LaRoccaC,Montovani A. From environment to food:The case of PCB. Ann Ist Super Sanita. 2006; 42(4):410-16.
26. Durand B, Dufour B, Fraisse D, Defour S, Duhem K, Le-Barillec K. Levels of PCDDs, PCDFs and dioxinlike PCBs in raw cow's milk collected in France in 2006. Chemosphere. 2008; 70:689-93. https://doi.org/10.1016/j. chemosphere.2007.06.057. PMid:17707881

27. Fagnani R, Beloti V, Battaglini AP, Dunga KS, Tamanani R. Organophosphorus and carbamates residues in milk and feedstuff supplied to dairy cattle. Pesquisa Veterinaria Brasileira. 2011; 31:598-602. https://doi. org/10.1590/S0100-736X2011000700009

28. USEPA (US Environmental Protection Agency) [Inter net]. 2005 Jan 24. Fluoxastrobin human health risk assessment. Document ID: EPA-HQ-OPP-2003-0129. Available from:http://www.epa.gov/opprd001/factsheets/

29. Currance PL, Clements B, Bronstein AC. Emergency care for hazardous materials exposure. 3rd ed. Louis, MO, Elsevier Mosby; 2005. p. 298-390.

30. Darnerud PO, Atuma S, Aule M, Bjerelius R, Glynn A, Grawe KP, Becker W. Dietary intake estimations of organohalogen contaminants (dioxins, PCB, PBDE and chlorinated pesticides, e.g. DDT) based on Swedish market basket data. Food Chem. Toxicol. 2006; 44:1597-606. https://doi.org/10.1016/j.fct.2006.03.011. PMid:16730400

31. Polder A, Savinowa TN, Tkachev A, Loken KB, Odland JO, Skarre JU. Levels and pattern of persistent organic pollutants (POPs) in selected food items from northwest Russia (1998-2002) and implications for dietary exposure. Sci. Total Environ. 2010; 3:5352-61. https:// doi.org/10.1016/j.scitotenv.2010.07.036. PMid:20719362

32. Schettino B, Gutierrez R, Ortiz R, Vega S, Uraban G, Ramirez A. Residues of legacy organochlorine contam inants in the milk of Alpine and Saanen goats from the central region of Mexico. Bulletin of Environmental Contamination and Toxicology. 2013; 91:154-9. https:// doi.org/10.1007/s00128-013-1005-8. PMid:23689930

33. Kan CA, Meijer GAL. The risk of contamination of food with toxic substances present in animal feed. Animal Feed Science and Technology. 2007; 133:84-108. https:// doi.org/10.1016/j.anifeedsci.2006.08.005

34. Risher JF, Franklin LM, Jerry FS. The toxicological effects of the carbamate insecticide aldicarb in mammals: A Re view. Environmental Health Perspectives. 1987; 72:26781. https://doi.org/10.1289/ehp.8772267. PMid:3304999 PMCid:PMC1474664 